\title{
Management Control Systems and Performance: The Mediating Role of Organisational Capabilities in Malaysia
}

\author{
TZE SAN ONG, ZOHREH HAGHSHENAS, BOON HENG TEH, BABATUNJI SAMUEL \\ ADEDEJI \& HUSSAIN BAKHSH MAGSI
}

\begin{abstract}
This study focuses on the interactive use of Management Control System (MCS) and the identification of threats and opportunities that enables management to respond quickly to changes in the environment. The study aims to examine, from a resource-based view (RBV) perspective, the relationship between interactive use of MCS and organisational capabilities (market responsiveness, strategic networking, process reliability and efficiency, innovativeness and learning) as well as their subsequent impact on organisational performance. An empirical study was conducted involving 70 public-listed companies in Malaysia. The analysis included the use of descriptive and multiple regression tests. The findings provide empirical evidence that interactive MCS facilitates the development of organisational capabilities and that organisational capabilities play a mediating role in the relationship between MCS interactive usage and organisational performance. This study indicates that companies in Malaysia still focus on financial measures rather than on non-financial ones in most of their decision making. Managers who are shortterm focused or financially oriented in their decision making may jeopardise the long-term sustainability of their organisations' performance.
\end{abstract}

Keywords: Management control system; organizational capabilities; organizational performance; Malaysia

\section{INTRODUCTION}

Business enterprises are experiencing rapid changes in customers' preferences, technological advancements and intensity of competition. In view of the dynamic business environment, it is crucial for organisations to continuously renew themselves and match their capabilities to the changing needs of customers for sustained performance (Danneels, 2002; Ojha, Struckell, Acharya, \& Patel, 2020). The capabilities of an organisation are a complex bundle of knowledge and skills that enables the firm to transform its available resources to achieve superior performance (Feng et al., 2017). The resource-based view (RBV) conceptualises an organisation as a bundle of resources and capabilities, and it posits that superior organisational performance is due to its rare, inimitable and non-substitutable resources and capabilities (Barney, 1991). Many studies have reported a positive link between organisational capabilities and organisational performance (Collis and Montgomery, 1995, 1998; Lee et al., 2001; Evans, Bridson, Byrom, \& Medway, 2005). Even though organisations may develop and adapt their capabilities in response to changes in their environments, the issue of what assist organisations to adapt their resource configurations over time has attracted increasing research interest (Helfat et al., 2009).

According to Simons (1990), Management Control Systems (MCS), which are formalised processes and procedures to serve the basic management functions of planning, coordination, controlling and evaluation, are useful not only for strategy implementation but also for formulation of new or revised strategies through frequent top management-subordinate interactions that empowers organisational learning and creation of competitive advantage. Certain management controls are made interactive to signal top management values and preferences, to monitor the environment for surprises and to ratify decisions by top management. The frequent and active debates and dialogues between top managers and their subordinates activate organisational learning that would lead to the emergence of new initiatives and strategies (Bedford, 2020).

MCS are levers for shaping and implementing organisational strategic agendas (Simons, 1994; Bedford, 2020). Management can use MCS to formalise beliefs, focus attention to enable learning, and thereby shape the development of new strategies and initiatives (Simons, 1991). Previous studies on the relationship between MCS and strategy have been found to be ambiguous and sometimes contradictory (Chapman, 1997; Langfield-Smith, 1997; Abernethy and Brownell, 1999; Chenhall, 2003; Ittner et al., 2003; Coller, Frigotto, \& Costa, 2018). Henri (2006) opines that the ambiguous findings of these studies may be due to varying definitions, conceptualisations and 
operationalisations of strategy and MCS, as well as the absence of a theoretical framework, such as that based on the $\mathrm{RBV}$, in their analyses of the relationship. MCS plays an important role as an antecedent to the development of organisational capabilities (Henri, 2006; Widener, 2007). Simons' (1995) Levers of Control (LOC) framework highlights "a complete range of possible controls" that includes the belief systems, boundary systems, diagnostic control systems and interactive control systems (Otley, 2003). The interactive use of MCS encourages frequent top manager-subordinate dialogues that often lead to new ideas and opportunity-seeking behaviours, and thereby facilitates formulation of innovative strategic initiatives to develop capabilities for competitive advantage (Toldbod \& van der Kolk, 2020).

Many past studies have focused on the relationship between strategy and performance. However, more recent ones look at the role of both organisational strategies and capabilities on performance, and according to Parnell (2011), substantial research opportunities exist in this arena. As a result, this current study will not look into the direct relationship between MCS and performance. A study by Ruzita and Parnell (2008) report that most firms in Malaysia pursued low-price strategies and gained their competitive advantage through low production cost and with greater emphasis on financial rather than on non-financial performance measures. An issue of increasing interest to both academics and practitioners is how organisations systematically utilise or extract value from the information generated by their strategic performance measurement systems (Franco and Bourne, 2003). This study intends to extend earlier strategy-performance studies by examining how interactive use of MCS facilitates development or reconfiguration of organisational capabilities that subsequently affects organisational performance. Organisational capabilities are expected to play a mediating role on the MCS-performance relationship, and thus would explain the mixed findings on the MCS-performance relationship in past studies. The findings of this study are expected to advance understanding of how using MCS interactively triggers development and re-configuration of organisational capabilities for enhancement of organisational performance.

This paper is organised as follows. A review of the extant literature is next, to be followed by a description of the theoretical framework and hypotheses. The next section describes the research design, after which are the results and the discussion sections. The paper ends with the conclusion and discussion of the implications.

\section{LITERATURE REVIEW}

\section{Management control system}

Current management control system literature is based on the contingency theory (Otley, 1980; Martin, 2020). Simons (1994) defines MCS as the formal information-based routines and procedures used by managers to maintain or alter patterns of organisational activities. The management routines and procedures typically generate information for managerial decision making relating to the planning, coordinating, control and evaluation activities in organisations. MCS is considered important because it enables organisations to track how they are performing (Agyemang \& Broadbent, 2015). Eyen though MCS have often been associated with implementation of organisational strategies, it can contribute to new strategy formulation by providing feedback and feedforward information to aid analyses of strategic uncertainties and risks (Simons, 1991). According to O'Reagan and Ghobadian (2004), resources and capabilities are developed and configured to support the goals articulated in the strategic plans of organisations. As MCS is often associated with implementation of an organisation's strategic plan, development of the requisite organisational capabilities are consequences of the effective functioning of the system. This is consistent with the argument of Bronza et al. (2012) that effective operational planning and managerial capabilities are crucial for identifying the resources for development of the required capabilities to achieve the desired operating performance. Their study found strong correlations among planning, capabilities and performance.

MCS can be used as a diagnostic control system to manage by-exception by identifying unfavourable performance deviations and guiding the affected activities toward attainment of the organisation's intended goals. It can also be used interactively through frequent dialogues between top managers and their subordinates to assess strategic uncertainties and to develop new strategic initiatives for sustenance of their firm's competitiveness. MCS is constantly challenged by changing strategies and competitive environment, which continuously demand new MCS requirements. On the other hand, MCS defines what is considered important for the development of strategy (Coller, Frigotto, \& Costa, 2018). Interactive use of MCS enables top managers to signal lower-level managers where the organisation's strategic focus is, and thereby facilitates organisational learning through formulation of new strategic initiatives and development of the desired organisational capabilities. In interactive MCS, the performance measurement system generates information feedback on the adequacy of past actions and its feedforward function influences the direction of future actions. 
The feedback and the feedforward information are useful for management to effectively assess their strategic success and the need for development of new strategic capabilities or to re-configure existing capabilities to adapt to the new environment for the creation and sustenance of organisational competitive advantage (Eisenhardt and Martin, 2000; Neely and Bourne, 2000; Chenhall, 2005; Grafton et al., 2010; Pavlov and Bourne, 2011). Organisations with a culture that strongly emphasises on flexibility values are more likely to respond quicker to external threats and opportunities than those with control value culture. Agbejule (2011) reports a higher positive performance for the flexible value firms when they adopt high interactive and low diagnostic use of the Management Accounting System (MAS). Arjalies and Mundy (2013) apply Simons' (1995) LOC framework to examine how organisations support their CSR agenda while utilising their MCS for strategic renewal that triggers organisational change. This study focuses on the interactive control systems in Simons' LOC framework to investigate how such control systems trigger strategic initiatives for the development of or re-configuration of organisational capabilities for superior organisational performance.

\section{Resource-based view (RBV) and capabilities}

RBV is an influential framework that provides the theoretical perspective for explaining organisational performance (Newbert, 2007). Based on RBV, organisations with resources that are valuable, rare, inimitable and nonsubstitutable could implement value-creating strategies that are not easily imitated by competitors; hence, they are able to sustain their competitive advantages (Barney, 1991). Thus, firms are heterogeneous from the resource-based perspective (Solesvik, 2018).

According to Stank et al. (2005), capabilities often refer to an organisation's capacity to utilise its resources to enhance its competitiveness through manufacturing flexibility, market responsiveness or/and cost effectiveness. Many organisational resources and capabilities may be and are very often developed or acquired by competitors, but it is the processes that are embedded in the organisation to integrate, build and reconfigure its internal and external competencies in response to the changing competitive landscape that is difficult to imitate, and thereby becomes a source of sustained competitive advantage (Teece et al., 1997). That embedded processes refer to dynamic capabilities that are defined as "the firm's processes that use resources - specifically the processes to integrate, reconfigure, gain and release resources - to match and even create market change (Solesvik, 2018). According to Eisenhardt and Martin (2000), dynamic capabilities are necessary, but they are not sufficient for competitive advantage. For an organisation to attain sustained competitive advantage, such embedded organisational decisionmaking processes must facilitate the development of new resource configurations or enhancement of existing resource configurations to create value for the organisation. Interactive use of MCS resembles very closely to the definition of dynamic capabilities. The frequent top manager-subordinate dialogues are the formalised routines or processes embedded in the organisation to assist identification and creation of the required resource configurations for implementation of its value-creating strategies.

Measuring organisational success is a continuous challenge for both researchers and managers. Financial measures have been used to indicate (past) success, but these measures are not determinants of future success. New performance measurement frameworks have emerged in recent years to extend organisational performance measurements beyond the traditional financial measures. Horngren, et al., (2012) defines the Balanced Scorecard (BSC) as a system for interpreting an organisation's mission and strategy in an integrated set of measures for performance measurement through providing a structure for implementing organisation's strategy via focusing on achieving financial and non-financial objectives. The BSC (Kaplan and Norton, 1992) is a frequently used framework that measures performance from four organisational perspectives: (i) financial, (ii) customer, (iii) internal process and (iv) innovation and learning.

Based on the BSC framework, market responsiveness, strategic networking, technology, innovation and learning capabilities are often used as the non-financial measures to proxy determinants of an organisation's future success (Lill, Wald, \& Munck, 2020).

\section{Market responsiveness}

Market responsiveness refers to the efficiency and effectiveness with which an organisation can sense, interpret, change its attitudes and act quickly on market stimuli. Market responsiveness is crucial to a company's performance because it manifests the firm's strategies in foreign markets and are actionable (Cadogan, 2012). Pehrsson (2019) demonstrates that market-driven responsiveness is an actionable component of strategic orientations that affect performance. The ability of an organisation to quickly respond to customers' needs and demands enhances customer satisfaction, and thereby is a value-creation capability critical for sustained competitive advantage.

\section{Strategic networking}


Networks can play a valuable but varied role for business activities. Not only can networks influence and impact on firm growth but also the nature and very shape of economic outcomes and improving firm's success (Obeng, 2018). Researchers have presented networking as a strategy to overcome the problems of Small and Medium Scale Enterprises (SMEs) and some selected network approaches and models (Thrikawala, 2011). Strategic networks facilitate procurement or mobilisation of external resources, identification and exploitation of market opportunities, thereby aid attainment of the organisational competitive goals. According to Hoskisson, Hitt and Ireland (2004), a strategic networking is a grouping of organisations that has been formed to create value through participation in an array of cooperative arrangements, such as alliances and joint ventures.

Sufficient time, effort and personnel have to be invested to build long-term relationship between partner firms (Sambasivan et al., 2011). Trust and commitment are two important components in an alliance relationship and crucial for enhancing and sustaining the relationship between partner firms (Morgan and Hunt, 1994; Kwon and Suh, 2005).

\section{Technology capability}

Technology capability is an organisation's ability to generate business value using its information technology assets and know-how; hence, if information technology is imperative for the industry, firms in the industry should aggressively cultivate their technology capability to successfully compete in the market (Chae, Koh \& Park, 2018). Technology capability comprises production technology and processes, knowledge and skills that create value for the organisation. The value of technology capability is often equated to enhance production efficiency and quality reliability that increase customer satisfaction. Enhanced customer satisfaction improves return on investment and market share (Hamzah et al., 2011).

Technological capability has been described as the collection of firms' individual specific efforts and strategies needed to choose, install, operate, maintain, understand, adapt, improve and develop technologies (Sobanke, Ilori \& Adegbite, 2012). Technological capability is one of the factors that enable a country and its enterprises perform some functions (especially innovation) critical to economic development and international competitiveness (Sobanke et al, 2014). Business processes are often redesigned through business process re-engineering (BPR) with effective integration of information technology to enable the business processes to be streamlined to enhance cost efficiency and more customer focused (Bhatt, 2000).

\section{Innovativeness}

Innovativeness refers to a firm's capacity to engage in innovation, i.e. introduction of new products, new processes or new marketing or organisational methods (Golgeci and Ponomarov 2015). Organisations with innovation capabilities are more successful in corporate renewals necessitated by the changing competitive landscape. Timely innovation of new products, services and processes are crucial to sustain organisational superior performance (Lawson and Somson, 2001). Innovativeness is indeed an important issue for managers who have to make decisions on which firms are the most suitable to cooperate and share knowledge with (Alegre and Pasamar, 2017).

\section{Learning orientation}

The field of strategic management has come up with a number of different approaches, including learning orientation, whose focus is on developing, acquiring and sharing knowledge within an organisation (Krzakiewicz \& Cyfert, 2019). Moreover, according to their study, the traditional approach to conceptualising learning orientation places the analytical focus on three components: (i) commitment to learning, (ii) shared vision of organisational development, and (iii) open-mindedness. Learning orientation has been recognised as a key process that contributes significantly to the success of an establishment (Oktavio, Kaihatu, \& Kartika, 2019).

\section{THEORETICAL FRAMEWORK}

The four levers of control in Simons' LOC framework are the (i) belief system, (ii) boundary system, (iii) diagnostic system and (iv) interactive system. The belief system is used to convey an organisation's values to employees, while the boundary system establishes restrictions on employees to guide and control their behaviours. These two levers of control serve as the underlying structure for the diagnostic system and the interactive system to operate. Diagnostic use of a control system involves comparison of performance against a set target to identify deviation, without questioning the fundamental assumptions underlying the performance target. Interactive use of a control system involves not only intensive use of the system by the superior and subordinates but also frequent face-to-face 
communication between the superior and his subordinates (Bisbe and Otley, 2004). The interactions between the superior and the subordinate groups in any business processes often trigger and uncover new strategies or initiatives. The controlling mechanisms in MCS are operated through the boundary and the diagnostic processes, while the enabling mechanisms are through the belief and the interactive processes (Arjalies and Mundy, 2013).

The aspects of MCS used interactively are those related to planning, controlling and evaluating profitgenerating activities. Exchange of information and debates on the underlying assumptions for action plans to assess strategic uncertainties are typical activities conducted in the frequent interactions between top-level managers and their subordinates. The nature of participation and involvement of top managers in the discussions and activities with their subordinates is that of empowering to facilitate knowledge sharing and organisational learning.

The theoretical framework, as shown in Figure 1, is developed based on a review of the theoretical and past empirical literature. The framework shows the relationships among MCS interactive usage, organisational capabilities and organisational performance. The interactive use of MCS is expected to have a positive impact on organisational capabilities, and organisational capabilities are expected to have a positive influence on organisational performance. Using MCS interactively is also expected to have an indirect effect on organisational performance through organisational capabilities (the mediator).

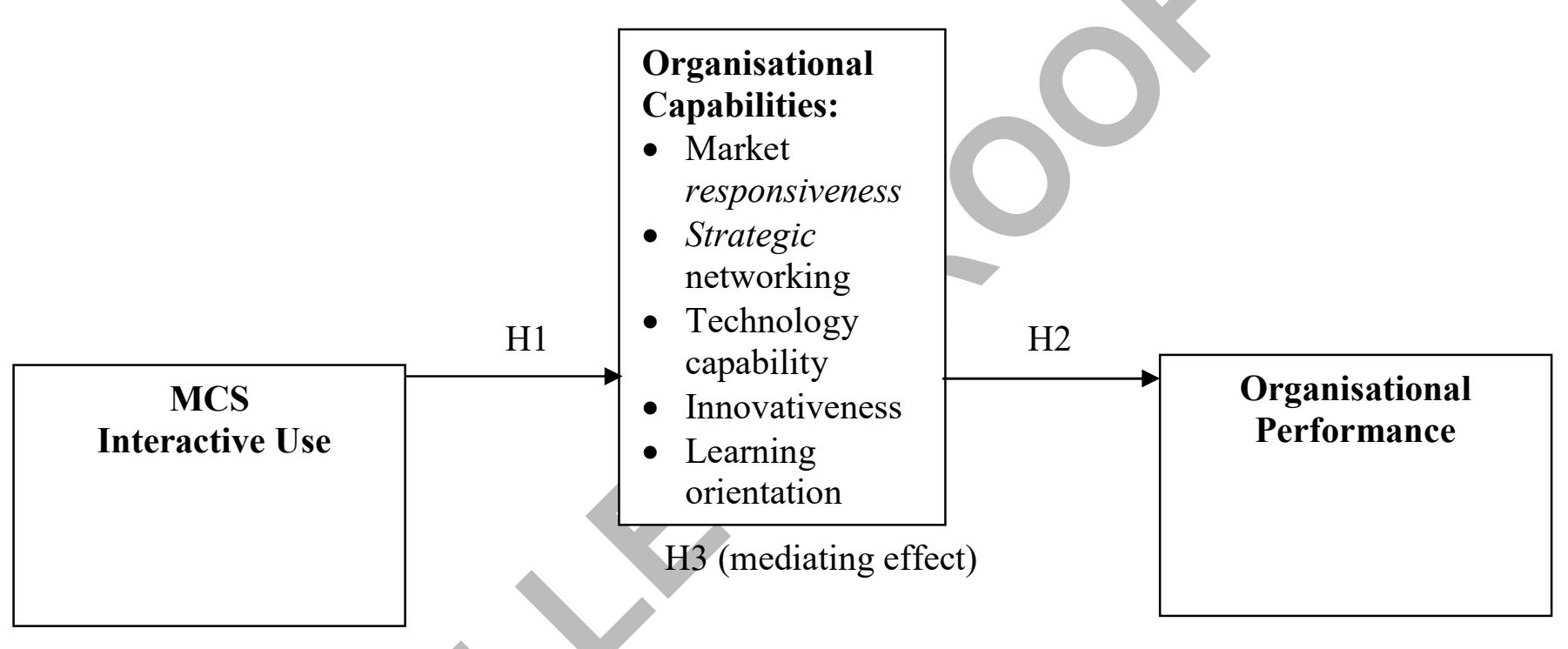

Figure 1: Research Framework

When MCS is used interactively, the frequent dialogues and debates between top managers and their subordinates provide opportunities for concerted efforts to assess emerging strategic uncertainties and formulate new strategic initiatives and action plans (Simons, 1991). The improved information communication of the organisation's strategic initiatives is expected to lead to development of the requisite organisational capabilities (Chenhall, 2005; Bisbe et $a l ., 2007)$. Top managers often choose to use certain parts of the MCS interactively to guide emergence of new strategies and strategic initiatives by signaling to their subordinates where the organisational strategic focus is and where learning and attention should be directed.

Past empirical studies have reported that interactive use of MCS facilitates development of organisational learning capability (Abernethy and Brownell, 1999; Henri, 2006) and enables top management to identify and monitor sources of innovation success (Abernethy and Brownell, 1999; Bisbe and Otley, 2004). According to Simons (1995), MCS interactive use fosters creative and inspirational forces that support development of creative ideas. He points out that the most innovative companies use their MCS more interactively than their less innovative competitors. Thus, the first main hypothesis is formulated as follows:

H1: There is a positive relationship between MCS interactive use and organisational capabilities.

Based on main hypothesis the sub hypotheses are as under:

H1a: There is a direct positive relationship between interactive use of MCS and market responsiveness. H1b: There is a direct positive relationship between interactive use of MCS and strategic networking. 
H1c: There is a direct positive relationship between interactive use of MCS and process reliability and efficiency.

H1d: There is a direct positive relationship between interactive use of MCS and innovativeness.

H1e: There is a direct positive relationship between interactive use of MCS and organizational learning.

Based on RBV, valuable, rare and inimitable resources or capabilities create competitive advantages for firms and that, in turn, contributes to performance differences among firms (Wernerfelt, 1984; Barney, 1991). When customers' needs are rapidly changing and environmental uncertainty is rising due to increasing competition, organisations that emphasise on innovation as a competitive strategy have better chances of survival. Innovativeness reflects the organisation's ability to effectively adapt and respond to environmental changes and uncertainties. It is one important capability that determines the organisation's long-term successful performance (Clark and Fujimoto, 1991; Capon et al., 1992; Bisbe and Otley, 2004).

Organisational learning also positively influences performance (Tippins and Sohi, 2003; Chenhall, 2005; Henri, 2006), and the same is true for market responsiveness (Nobel et al., 2006). Previous studies also provide evidence that strong mutual trust between partner firms leads to more beneficial cooperation between them, and thereby improve performances of the partner firms (Morgan and Hunt, 1994; Kwon and Suh, 2005). The second main hypothesis is as below:

$\mathrm{H}_{2}$ : There is a positive relationship between organisational capabilities and organisational performance.

The sub-hypotheses are:

H2a: There is a direct positive relationship between market responsiveness and organizational performance.

H2b: There is a direct positive relationship between strategic networking and organizational performance.

H2c: There is a direct positive relationship between process reliability and efficiency and organizational performance.

H2d: There is a direct positive relationship between innovativeness and organizational performance.

H2e: There is a direct positive relationship between organizational learning and organizational performance.

Due to the mixed findings of prior studies and the absence of an established theoretical argument that there is a direct relationship between using MCS interactively and organisational performance, Bisbe and Otley (2004) propose that there may be an indirect relationship between MCS and organisational performance. Henri (2006) similarly opines that interactive use of the performance measurement system (PMS) in MCS can influence indirectly organisational performance through the organisational capabilities that the PMS is monitoring. Organisational capabilities are playing a mediating role to explain the relationship between interactive use of MCS and performance. The strategic initiatives identified through such a use are expected to lead to development of the requisite organisational capabilities to sustain organisational competitiveness. Webster (2006) reports an indirect relationship between using MCS interactively and performance. Thus, the third main hypothesis is as follows:

$\mathrm{H}_{3}$ : Interactive use of MCS mediates between organisational capabilities and organisational performance.

\section{METHODOLOGY}

\section{Sample and data collection}

The sampling frame for this study consists of 858 companies listed in Bursa Malaysia (previously known as Kuala Lumpur Stock Exchange). Copies of the questionnaires were sent to the Chief Executive Officers (CEO) or the financial controllers, who are top-level managers with adequate knowledge about their business strategic focuses, use of MCS and organisational performance, of these companies. The names and e-mail addresses of the respondents were obtained from the companies' websites. The questionnaires were sent to the respondents electronically as email attachments, using Mailchimp. Each questionnaire was accompanied by a cover letter explaining the purpose of the study and assured the respondent of anonymity and confidentiality of the data collected. 
A common problem encountered in Internet surveys is that many of the e-mail addresses obtained from corporate websites are invalid either because owners of these e-mail addresses have left the organisations or have since changed their e-mail addresses. Another problem is that many of the e-mails sent are deleted without being read. According to a report from Mailchimp, only 300 of the 858 e-mails sent were read but only 81 of them clicked on the link. Twenty of the 81 who clicked responded within the three-week duration given. A follow-up email and call were made to each of the remaining 61 respondents, who had read but had not yet returned their questionnaires, to remind him/her to complete and return the questionnaire within the next three weeks. Another 43 completed questionnaires were received after the first reminder. A second reminder was sent and only an additional 7 questionnaires were received. Finally, a total of 70 duly completed questionnaires were obtained for subsequent data analyses. The response rate was $23.33 \%$ (70 out of the 300 e-mails actually read), which could be considered as reasonable in view of the low response rate that is generally expected for social science research study (Brennan and Hoek, 1992).

A test for non-response bias was carried out to ascertain whether there were significant differences between the mean scores of the early and late responses (those that came after the reminders). Results of the independent sample t-tests indicate no non-response bias as there are no statistically significant differences between the mean scores of the two groups.

\section{Research instrument}

A structured questionnaire was developed for data collection. The questionnaire contained 4 sections: Section A dealt with the extent of MCS interactive use; Section B gathered details of existence of the 5 types of organisational capabilities examined in this study; Section C focused on measures of organisational performance, and Section D requested background information of the respondents and his/her organisations.

\section{Measurements of constructs}

Measures of constructs examined in this study were adapted from items validated in prior research studies to enable findings of this study to better relate to past research efforts (Langfield-Smith, 1997). Table 1 presents the number of items adapted from prior studies for measuring the variables in this study.

Table 1: Measurement of variables

\begin{tabular}{|c|c|c|c|c|}
\hline No. & Variable & $\begin{array}{l}\text { No. of } \\
\text { items }\end{array}$ & Source & Scale \\
\hline 1. & MCS interactive use & 5 & $\begin{array}{l}\text { Abernethy and } \\
\text { Brownel (1999); } \\
\text { Davila (2000) }\end{array}$ & $\begin{array}{l}\text { Likert Scale } 1 \text { to } 5(1=\text { Not at } \\
\text { all to } 5=\text { Very extensive })\end{array}$ \\
\hline 2. & $\begin{array}{l}\text { Organisational capabilities: } \\
\text { Market responsiveness } \\
\text { Strategic networking } \\
\text { Technology capability } \\
\text { Innovativeness } \\
\text { Learning orientation }\end{array}$ & $\begin{array}{l}4 \\
7 \\
9 \\
5 \\
3\end{array}$ & $\begin{array}{l}\text { Nobel et al. } \\
\text { (2006); } \\
\text { Sambasivan et al. } \\
\text { (2011); } \\
\text { Snell and Dean } \\
\text { (1992); } \\
\text { Burke (1989); } \\
\text { Hult (1998); }\end{array}$ & $\begin{array}{l}\text { Market responsiveness }(1= \\
\text { Not responsive to } 5=\text { Very } \\
\text { responsive); strategic } \\
\text { networking }(1=\text { Strongly } \\
\text { disagree to } 5=\text { Strongly } \\
\text { agree); technological } \\
\text { capabilities }(1=\text { Not at all to } \\
5=\text { Very extensive }) \text {; } \\
\text { innovativeness }(1=\text { Strongly } \\
\text { disagree to } 5=\text { Strongly } \\
\text { agree), learning orientation } \\
\text { (1= Not reflective to } 5=\text { Very } \\
\text { reflective) }\end{array}$ \\
\hline 3. & $\begin{array}{l}\text { Organisational performance: } \\
\text { Financial performance } \\
\text { Non-financial performance }\end{array}$ & $\begin{array}{l}4 \\
8\end{array}$ & $\begin{array}{l}\text { Govindarajan, } \\
\text { (1986) }\end{array}$ & $\begin{array}{l}(1=\text { Well below the industry } \\
\text { average to } 5=\text { Well above the } \\
\text { industry average) }\end{array}$ \\
\hline
\end{tabular}

Factor analysis, which uses principal components analysis as the extraction method and varimax as the orthogonal rotation method, identified the five dimensions of organisational capabilities with $72.83 \%$ of the total variance explained. Items with factor loading $<0.5$ or factor loading $>0.5$ across two or more factors were eliminated. The remaining items used to measure market responsiveness, strategic networking, technology 
capability, innovativeness and learning orientation after the factor analysis are 4, 7,6, 4 and 3, respectively. Similarly, the two dimensions of organisational performance were identified with $64.88 \%$ of the total variance explained. The items that were used to measure financial performance and the non-financial performance are 4 and 3 , respectively. The use of MCS interactively was measured by 5 items with $58.92 \%$ of the total variance explained.

The internal reliability of each variable was assessed by its Cronbach Alpha coefficient. Most of the reliability coefficients of the variables, as shown in Table 3, are above 0.7 , except for innovativeness with a reliability coefficient of 0.6. The coefficients are, however, all within the acceptable range (Nunnally, 1978). The normality tests indicate that skewness and kurtosis of all the variables are within the -2 and +2 range; therefore, the variables can be assumed to be normally distributed.

\section{RESULTS}

\section{Demographic profile of respondents}

As shown in Table 2, 41.4\% of the respondents held top or senior level management position and $45.7 \%$ were middle-level managers. About $42.9 \%$ were aged above 40 . In terms of working experience, $31.4 \%$ had worked more than 10 years in their current organisations and $91.3 \%$ of the respondents worked in the accounting and finance section. The companies were largely locally owned $(92.9 \%)$ and $51.4 \%$ of the sample companies were in the manufacturing sector. In terms of size, $58.5 \%$ of the sample companies reported more than RM100 million of annual sales turnover and $55.7 \%$ had more than 250 employees.

Table 2: Demographic profile of respondents $(n=70)$

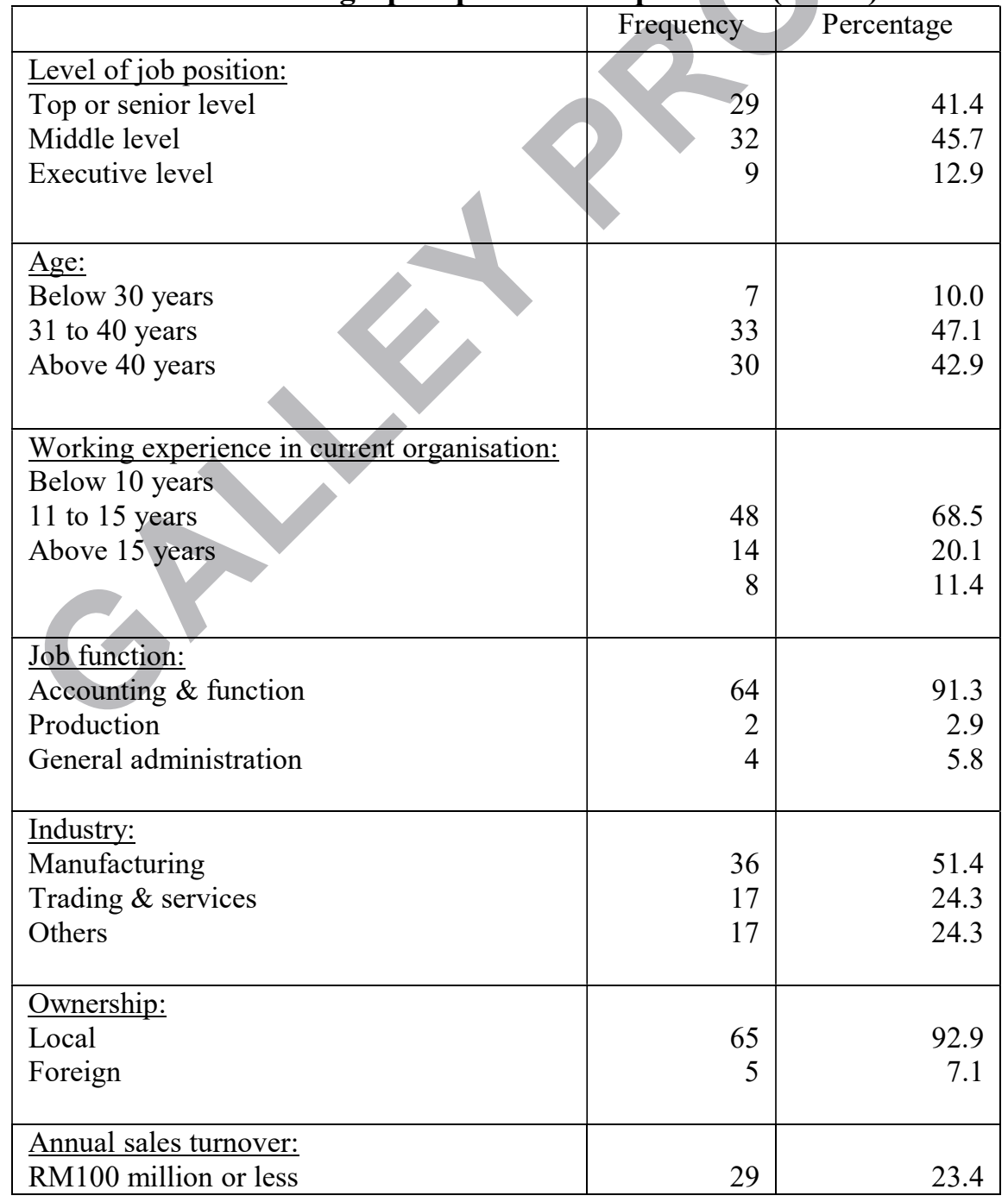




\begin{tabular}{|l|r|r|}
\hline RM101 million to RM500 million & 31 & 44.2 \\
Above RM500 million & 10 & 16.4 \\
\hline Number of employees: & 31 & \\
Less than 250 & 18 & 44.3 \\
251 to 500 & 21 & 25.7 \\
Above 500 & & 30.0 \\
\hline
\end{tabular}

\section{Descriptive Statistics}

Table 3 summarises the descriptive statistics of the variables. On average, MCS was not extensively used interactively among the sample companies, as indicated by its mean score of 3.28. Of the five organisational capabilities, the mean score of learning orientation is the highest at 3.87, followed by market responsiveness at 3.59 . Technology capability has the lowest mean score of 2.40 but with the highest standard deviation. The overall mean score of organisational performance is 3.23 .

Table 3: Means and standard deviations of variables

\begin{tabular}{|c|c|c|c|c|c|}
\hline Variable & Mean & $\begin{array}{c}\text { Standard } \\
\text { Deviation }\end{array}$ & Minimum & Maximum & $\begin{array}{c}\text { Cronbach } \\
\text { Alpha }\end{array}$ \\
\hline MCS interactive use & 3.28 & 0.64 & 1.80 & 5.00 & 0.823 \\
\hline $\begin{array}{l}\text { Overall organisational capabilities: } \\
\text { Market responsiveness }\end{array}$ & 3.15 & 0.50 & 1.50 & 4.04 & 0.728 \\
\hline Strategic networking & 3.59 & 0.66 & 1.50 & 4.75 & 0.848 \\
\hline Technology capability & 3.29 & 0.69 & 1.00 & 4.71 & 0.879 \\
\hline Innovativeness & 2.40 & 0.85 & 1.00 & 4.00 & 0.861 \\
\hline Learning orientation & 3.03 & 0.69 & 1.00 & 4.50 & 0.634 \\
\hline & 3.87 & 0.67 & 2.67 & 5.00 & 0.794 \\
\hline Organisational performance: & 3.23 & 0.59 & 1.86 & 5.00 & 0.872 \\
\hline Financial performance & 3.06 & 0.69 & 1.50 & 5.00 & 0.915 \\
\hline Non-financial performance & 347 & 0.65 & 1.67 & 5.00 & 0.741 \\
\hline
\end{tabular}

Scale: $1=$ extremely low; 5 = extremely high

Table 4 shows the correlation matrix of the variables. It indicates that the interactive use of MCS is significantly correlated with all 5 organisational capabilities as well as the organisational performance variable. Results of the multicollinearity test, however, indicate no serious multicollinearity problem because the values of Tolerance and VIF (Variance Inflation Factor) are above 0.1 and not more than 10 , respectively.

Table 4: Correlation matrix of variables

\begin{tabular}{|l|l|l|l|l|l|l|l|}
\hline \multicolumn{1}{|c|}{ Variable } & \multicolumn{1}{|c|}{ V1 } & \multicolumn{1}{|c|}{ V2 } & \multicolumn{1}{|c|}{ V3 } & \multicolumn{1}{c|}{ V5 } & V6 & V7 \\
\hline Interactive use of MCS (V1) & 1.00 & & & & & & \\
\hline Market responsiveness (V2) & $0.36^{* *}$ & 1.00 & & & & & \\
\hline Strategic networking (V3) & $0.44^{* *}$ & $0.68^{* *}$ & 1.00 & & & & \\
\hline $\begin{array}{l}\text { Process reliability \& } \\
\text { efficiency (V4) }\end{array}$ & $0.46^{* *}$ & $0.38^{* *}$ & $0.34^{* *}$ & 1.00 & & & \\
\hline Innovativeness (V5) & $0.34^{* *}$ & $0.47^{* *}$ & $0.53^{* *}$ & $0.25^{*}$ & 1.00 & & \\
\hline Learning (V6) & $0.30^{* *}$ & $0.27^{*}$ & 0.21 & 0.12 & $0.38^{* *}$ & 1.00 & \\
\hline $\begin{array}{l}\text { Organisational performance } \\
\text { (V7) }\end{array}$ & $0.43^{* *}$ & $0.42^{* *}$ & $0.45^{* *}$ & $0.42^{* *}$ & $0.41^{* *}$ & $0.31^{* *}$ & 1.00 \\
\hline
\end{tabular}

Note: ${ }^{*} \mathrm{p}<0.05 ; * * \mathrm{P}<0.01$

MCS interactive use and organisational capabilities 
The results of the regression of MCS interactive usage on organisational capabilities, with size (sales) and industry included as control variables, are summarised in Table 5. The results indicate that using MCS interactively is significantly associated with organisational capabilities $(\mathrm{p}=0.000)$; hence, hypothesis $\mathrm{H}_{1}$ is fully supported.

Table 5: Result of regression of MCS interactive use on organisational capabilities

\begin{tabular}{|l|r|r|r|r|r|}
\hline & \multicolumn{2}{|c|}{ Unstandardized coefficient } & \multicolumn{1}{c|}{$\begin{array}{c}\text { Standardized } \\
\text { coefficient }\end{array}$} & \multirow{2}{*}{ t-value } & \multicolumn{1}{c|}{ sig. } \\
\hline & \multicolumn{1}{|c|}{ B } & Std. error & \multicolumn{1}{c|}{ Beta } & \multicolumn{1}{c|}{ t-val } \\
\hline Constant & 1.756 & 0.307 & & 5.715 & 0.000 \\
\hline Size & 0.016 & 0.026 & 0.064 & 0.630 & 0.531 \\
\hline Industry & -0.034 & 0.020 & -0.173 & -1.695 & 0.095 \\
\hline MCS interactive use & 0.435 & 0.085 & 0.529 & 5.101 & 0.000 \\
\hline
\end{tabular}

$\mathrm{F}=13.016 ; \mathrm{p}=0.00 ; \mathrm{R}^{2}=0.379 ; \operatorname{Adj} \mathrm{R}^{2}=0.35$.

Further regression analysis of interactive MCS on each of the organisational capabilities, as shown in Table 6, also indicates a significant positive relationship between MCS interactive use and each of the five organisational capabilities. Based on the $\mathrm{R}^{2}$ statistics, using MCS interactively explains $30.9 \%$ of variations in technological capability, but only $12.7 \%$ for variations in the learning orientation.

Table 6: Result of regression of MCS interactive use on each of the organisational capabilities

\begin{tabular}{|c|c|c|c|c|c|c|c|c|c|c|}
\hline & \multicolumn{2}{|c|}{$\begin{array}{l}\text { Market } \\
\text { responsiveness }\end{array}$} & \multicolumn{2}{|c|}{$\begin{array}{l}\text { Strategic } \\
\text { networking }\end{array}$} & \multicolumn{2}{|c|}{$\begin{array}{l}\text { Technology } \\
\text { capability }\end{array}$} & \multicolumn{2}{|c|}{ Innovativeness } & \multicolumn{2}{|c|}{$\begin{array}{l}\text { Learning } \\
\text { orientation }\end{array}$} \\
\hline & t-value & sig. & t-value & sig. & $\mathrm{t}$-value & sig. & $t$-value & sig. & t-value & sig. \\
\hline Constant & 5.87 & 0.00 & 3.58 & 0.00 & 0.88 & 0.38 & 4.06 & 0.00 & 6.30 & 0.00 \\
\hline Size & 1.93 & 0.06 & 0.58 & 0.56 & 1.22 & 0.23 & -0.98 & 0.33 & -1.92 & 0.06 \\
\hline Industry & -2.20 & 0.03 & -0.56 & 0.58 & -1.80 & 0.08 & -0.81 & 0.42 & 0.48 & 0.64 \\
\hline \multirow{2}{*}{$\begin{array}{l}\text { MCS } \\
\text { interactive } \\
\text { use }\end{array}$} & 2.01 & $0.05^{*}$ & 3.62 & $0.00 * *$ & 3.89 & $0.00^{* *}$ & 2.91 & $0.01 *$ & 2.69 & $0.01^{*}$ \\
\hline & \multicolumn{2}{|c|}{$\begin{array}{l}F=6.371 \\
p=0.001 \\
R^{2}=0.230 \\
\text { Adj } R^{2}=0.194\end{array}$} & \multicolumn{2}{|c|}{$\begin{array}{l}\mathrm{F}=5.819 \\
\mathrm{p}=0.001 \\
\mathrm{R}^{2}=0.214 \\
\text { Adj } \mathrm{R}^{2}=0.177\end{array}$} & \multicolumn{2}{|c|}{$\begin{array}{l}\mathrm{F}=9.531 ; \\
\mathrm{p}=0.000 \\
\mathrm{R}^{2}=0.309 \\
\text { Adj } \mathrm{R}^{2}=0.276\end{array}$} & \multicolumn{2}{|c|}{$\begin{array}{l}\mathrm{F}=3.637 \\
\mathrm{p}=0.017 \\
\mathrm{R}^{2}=0.146 \\
\text { Adj } \mathrm{R}^{2}=0.106\end{array}$} & \multicolumn{2}{|c|}{$\begin{array}{l}\mathrm{F}=3.106 \\
\mathrm{p}=0.033 \\
\mathrm{R}^{2}=0.127 \\
\text { Adj } \mathrm{R}^{2}=0.086\end{array}$} \\
\hline
\end{tabular}

Note: $* *$ sig. at $0.00 ; *$ sig. at 0.05

\section{Organisational capabilities and performance}

Table 7 shows the results of the regression of organisational capabilities on organisational performance. It shows that organisational capabilities are positively and significantly associated with overall organisational performance as well as with the financial and the non-financial dimensions of the performance variable. Hypothesis $\mathrm{H}_{2}$ is also strongly supported.

Table 7: Results of regression of organisational capabilities on organisational performance

\begin{tabular}{|l|r|r|r|r|r|r|}
\hline & \multicolumn{1}{|c|}{ Overall performance } & \multicolumn{1}{c|}{ Financial performance } & \multicolumn{2}{c|}{ Non-financial performance } \\
\hline & \multicolumn{1}{c|}{ t-value } & \multicolumn{1}{c|}{ sig. } & \multicolumn{1}{c|}{ t-value } & \multicolumn{1}{c|}{ sig. } & \multicolumn{1}{c|}{ t-value } & \multicolumn{1}{c|}{ sig. } \\
\hline Constant & 2.65 & 0.01 & 1.02 & 0.31 & 3.55 & 0.00 \\
\hline Size & 2.82 & 0.01 & 2.86 & 0.01 & 1.61 & 0.11 \\
\hline Industry & 1.55 & 0.13 & 2.12 & 0.04 & 0.22 & 0.83 \\
\hline $\begin{array}{l}\text { Organisational } \\
\text { capability }\end{array}$ & 4.64 & $0.00^{* *}$ & 4.55 & $0.00^{* *}$ & 2.85 & $0.01^{*}$ \\
\hline
\end{tabular}




\begin{tabular}{|l|l|l|l|}
\hline & $\mathrm{F}=11.661 ; \mathrm{p}=0.000 ;$ & $\mathrm{F}=11.419 ; \mathrm{p}=0.000 ;$ & $\mathrm{F}=4.503 ; \mathrm{p}=0.006 ;$ \\
& $\mathrm{R}^{2}=0.353 ;$ & $\mathrm{R}^{2}=0.349 ;$ & $\mathrm{R}^{2}=0.174 ;$ \\
& Adj $\mathrm{R}^{2}=0.323$ & & Adj $\mathrm{R}^{2}=0.318$
\end{tabular}

Note: ${ }^{*}$ sig. at $0.00 ; *$ sig. at 0.01

Results of the multiple regression of individual organisational capability on organisational performance, as shown in Table 8, however, show that only technology capability and learning orientation are marginally associated with the overall organisational performance. Technology capability is significantly associated with financial performance, while learning orientation is only marginally associated with that performance dimension. None of the organisational capabilities is significantly associated with the non-financial dimension of organisational performance.

Table 8: Results of regression of individual organisational capabilities on organisational performance

\begin{tabular}{|c|c|c|c|c|c|c|}
\hline & \multicolumn{2}{|c|}{ Overall performance } & \multicolumn{2}{|c|}{ Financial performance } & \multicolumn{2}{|c|}{ Non-financial performance } \\
\hline & t-value & sig. & t-value & sig. & t-value & sig. \\
\hline Constant & 1.95 & 0.06 & 0.64 & 0.52 & 2.76 & 0.01 \\
\hline Size & 2.81 & 0.01 & 3.10 & 0.00 & 1.36 & 0.18 \\
\hline Industry & 1.30 & 0.20 & 1.80 & 0.08 & 0.19 & 0.85 \\
\hline Market responsiveness & 0.35 & 0.72 & -0.29 & 0.77 & 0.99 & 0.33 \\
\hline Strategic networking & 1.09 & 0.28 & 0.90 & 0.37 & 0.89 & 0.38 \\
\hline Technology capability & 1.87 & $0.07 *$ & 2.38 & $0.02 * *$ & 0.53 & 0.60 \\
\hline Innovative & 0.83 & 0.41 & 1.24 & 0.22 & 0.01 & 0.99 \\
\hline \multirow[t]{2}{*}{ Learning orientation } & 1.64 & $0.10^{*}$ & 1.86 & $0.07 *$ & 0.74 & 0.46 \\
\hline & \multicolumn{2}{|c|}{$\begin{array}{l}\mathrm{F}=4.918 ; \mathrm{p}=0.000 \\
\mathrm{R}^{2}=0.365 \\
\text { Adj } \mathrm{R}^{2}=0.29\end{array}$} & \multicolumn{2}{|c|}{$\begin{array}{l}\mathrm{F}=5.332 ; \mathrm{p}=0.000 ; \\
\mathrm{R}^{2}=0.383 ; \\
\text { Adj } \mathrm{R}^{2}=0.312\end{array}$} & \multicolumn{2}{|c|}{$\begin{array}{l}\mathrm{F}=1.998 ; \mathrm{p}=0.07 \\
\mathrm{R}^{2}=0.189 ; \\
\text { Adj } \mathrm{R}^{2}=0.094\end{array}$} \\
\hline
\end{tabular}

Note: $* *$ sig. at $0.05 ; *$ sig. at 0.10

\section{Mediating effects of organisational capabilities}

A hierarchical mediated regression analysis was carried out to test the mediating effect of organisational capabilities on the relationship between the interactive use of MCS and organisation performance (Baron and Kenny, 1986). Results in Table 5 indicate that MCS interactive usage (IV) has a significant positive association with organisational capabilities (MV) and Table 7 shows that organisational capabilities (mediating variable) are significantly related to organisational performance (dependent variable). Results of the regression of an interactive MCS on organisation performance before (Model 1) and after (Model 2) inclusion of organisational capabilities (mediating variable) in the regression model are presented in Table 9. Mediation effect exists when the significance of the relationship between interactive MCS usage (independent variable) and organisational performance (dependent variable) is either reduced or become non-significant when organisational capabilities (mediating variable) is controlled.

Table 9: Mediating effect of organisational capabilities on relationship between MCS interactive use and organisational performance

\begin{tabular}{|l|c|c|c|c|c|c|c|c|c|c|c|c|}
\hline & \multicolumn{3}{|c|}{ Overall Performance } & \multicolumn{3}{c|}{ Financial performance } & \multicolumn{2}{c|}{ Non-financial performance } \\
\hline & \multicolumn{2}{|c|}{ Model 1 } & \multicolumn{2}{|c|}{ Model 2 } & \multicolumn{2}{c|}{ Model 1 } & \multicolumn{2}{c|}{ Model 2 } & \multicolumn{2}{c|}{ Model 1 } & \multicolumn{2}{c|}{ Model 2} \\
& $\begin{array}{c}\mathrm{t}- \\
\text { valu } \\
\mathrm{e}\end{array}$ & Sig & $\begin{array}{c}\mathrm{t}- \\
\text { valu } \\
\mathrm{e}\end{array}$ & Sig & $\begin{array}{c}\mathrm{t}- \\
\text { valu } \\
\mathrm{e}\end{array}$ & Sig & $\begin{array}{c}\mathrm{t}- \\
\text { valu } \\
\mathrm{e}\end{array}$ & Sig & $\begin{array}{c}\mathrm{t}- \\
\text { valu } \\
\mathrm{e}\end{array}$ & Sig & $\begin{array}{c}\mathrm{t}- \\
\text { value }\end{array}$ & Sig \\
\hline Constant & 4.85 & 0.00 & 2.27 & 0.03 & 3.00 & 0.00 & 0.70 & 0.49 & 5.36 & 0.00 & 3.24 & 0.00 \\
\hline
\end{tabular}




\begin{tabular}{|c|c|c|c|c|c|c|c|c|c|c|c|c|}
\hline Size & 2.75 & 0.01 & 2.70 & 0.01 & 2.79 & 0.01 & 2.73 & 0.01 & 1.67 & 0.10 & 1.54 & 0.13 \\
\hline Industry & 0.86 & 0.39 & 1.62 & 0.11 & 1.43 & 0.16 & 2.19 & 0.03 & $\begin{array}{r}- \\
0.19\end{array}$ & 0.85 & 0.26 & 0.80 \\
\hline $\begin{array}{l}\text { MCS } \\
\text { interactive } \\
\text { use }\end{array}$ & 3.01 & $\begin{array}{l}0.00 \\
* * *\end{array}$ & 0.90 & 0.37 & 3.02 & $\begin{array}{r}0.00 * * \\
*\end{array}$ & 0.96 & 0.34 & 1.86 & $\begin{array}{r}0.07 \\
*\end{array}$ & 0.46 & 0.65 \\
\hline \multirow[t]{2}{*}{$\begin{array}{l}\text { Organisatio } \\
\text { nal } \\
\text { capabilities }\end{array}$} & & & 3.43 & $\begin{array}{r}0.00^{*} \\
\quad * *\end{array}$ & & & 3.32 & $\begin{array}{r}0.00 \\
* * *\end{array}$ & & & 2.14 & $0.04 * *$ \\
\hline & \multicolumn{2}{|c|}{$\begin{array}{l}F=6.840 \\
p=0.000 \\
R^{2}=0.243 \\
\text { Adj } \\
R^{2}=0.207\end{array}$} & \multicolumn{2}{|c|}{$\begin{array}{l}\mathrm{F}=8.922 \\
\mathrm{p}=0.000 ; \\
\mathrm{R}^{2}=0.362 ; \\
\mathrm{Adj} \\
\mathrm{R}^{2}=0.321\end{array}$} & \multicolumn{2}{|c|}{$\begin{array}{l}\mathrm{F}=6.952 \\
\mathrm{p}=0.000 \\
\mathrm{R}^{2}=0.246 \\
\mathrm{Adj} \\
\mathrm{R}^{2}=0.210\end{array}$} & \multicolumn{2}{|c|}{$\begin{array}{l}\mathrm{F}=8.781 \\
\mathrm{p}=0.000 \\
\mathrm{R}^{2}=0.358 \\
\text { Adj } \mathrm{R}^{2}=0.317\end{array}$} & \multicolumn{2}{|c|}{$\begin{array}{l}\mathrm{F}=2.84 ; \\
\mathrm{p}=0.045 \\
\mathrm{R}^{2}=0.117 \\
; \\
\text { Adj } \\
\mathrm{R}^{2}=0.076\end{array}$} & \multicolumn{2}{|c|}{$\begin{array}{l}\mathrm{F}=3.39 ; \mathrm{p}=0.014 ; \\
\mathrm{R}^{2}=0.177 \\
\text { Adj } \mathrm{R}^{2}=0.125\end{array}$} \\
\hline
\end{tabular}

Note: $* * *$ sig. at $0.00 ; * *$ sig. at $0.05 ; *$ sig. at 0.10

Models 1 and 2, as presented in Table 9, support hypothesis $\mathrm{H}_{3}$ that organisational capabilities fully mediate the relationship between the use of MCS interactively and organisational performance. Model 1 in Table 9 shows that interactive use of MCS is significantly associated with the overall organisational performance and the financial dimension of the performance variable. Its impact on the non-financial dimension of the performance variable, however, is only marginally significant. Model 2 indicates that the effects of using MCS interactively on the three performance measures become insignificant after inclusion of the mediating variable - organisational capabilities.

Sub-analyses by individual organisational capabilities, as shown in Table 8, indicate that only technology capability and learning orientation have met the conditions required for testing of the mediation effect. Therefore, subsequent testing of the mediation effect of individual organisational capabilities is limited to only those of technology capability and learning orientation. Table 10 and Table 11 present the results of testing of the mediation effects of technology capability and learning orientation, respectively.

Table 10: Mediating effect of technology capability on relationship between MCS interactive use and organisational performance

\begin{tabular}{|c|c|c|c|c|c|c|c|c|c|c|c|c|}
\hline & \multicolumn{4}{|c|}{ Overall Performance } & \multicolumn{4}{|c|}{ Financial performance } & \multicolumn{4}{|c|}{ Non-financial performance } \\
\hline & \multicolumn{2}{|c|}{ Model 1} & \multicolumn{2}{|c|}{ Model 2} & \multicolumn{2}{|c|}{ Model 1} & \multicolumn{2}{|c|}{ Model 2} & \multicolumn{2}{|c|}{ Model 1} & \multicolumn{2}{|c|}{ Model 2} \\
\hline & $\begin{array}{c}\mathrm{t}- \\
\text { value }\end{array}$ & Sig & $\begin{array}{c}\mathrm{t}- \\
\text { value }\end{array}$ & Sig & $\begin{array}{c}\mathrm{t}- \\
\text { value }\end{array}$ & Sig & $\begin{array}{c}\mathrm{t}- \\
\text { value }\end{array}$ & Sig & $\begin{array}{c}\mathrm{t}- \\
\text { value }\end{array}$ & Sig & $\begin{array}{c}\mathrm{t}- \\
\text { value }\end{array}$ & Sig \\
\hline Constant & 4.85 & 0.00 & 4.70 & 0.00 & 3.00 & 0.00 & 2.83 & 0.01 & 5.36 & 0.00 & 5.25 & 0.00 \\
\hline Size & 2.75 & 0.01 & 2.51 & 0.16 & 2.79 & 0.01 & 2.51 & 0.02 & 1.67 & 0.10 & 1.58 & 0.12 \\
\hline Industry & 0.86 & 0.39 & 1.20 & 0.23 & 1.43 & 0.16 & 1.90 & 0.06 & -0.19 & 0.85 & -0.10 & 0.92 \\
\hline $\begin{array}{l}\text { MCS } \\
\text { interactive } \\
\text { use }\end{array}$ & 3.01 & $0.00^{* * *}$ & 2.03 & $0.05 * *$ & 3.02 & $0.00^{* * *}$ & 1.86 & $0.07^{*}$ & 1.86 & $0.07 *$ & 1.50 & 0.14 \\
\hline \multirow[t]{2}{*}{$\begin{array}{l}\text { Technology } \\
\text { capability }\end{array}$} & & & 1.62 & 0.11 & & & 2.15 & $0.04 * *$ & & & 0.37 & 0.71 \\
\hline & \multicolumn{2}{|c|}{$\begin{array}{l}\mathrm{F}=6.840 \\
\mathrm{p}=0.000 \\
\mathrm{R}^{2}=0.243 \\
\text { Adj } \mathrm{R}^{2}=0.207\end{array}$} & \multicolumn{2}{|c|}{$\begin{array}{l}\mathrm{F}=5.915 \\
\mathrm{p}=0.000 \\
\mathrm{R}^{2}=0.273 \\
\text { Adj } \mathrm{R}^{2}=0.227\end{array}$} & \multicolumn{2}{|c|}{$\begin{array}{l}\mathrm{F}=6.952 \\
\mathrm{p}=0.000 \\
\mathrm{R}^{2}=0.246 \\
\text { Adj } \mathrm{R}^{2}=0.210\end{array}$} & \multicolumn{2}{|c|}{$\begin{array}{l}F=6.666 \\
p=0.000 \\
R^{2}=0.297 \\
\text { Adj } R^{2}=0.253\end{array}$} & \multicolumn{2}{|c|}{$\begin{array}{l}\mathrm{F}=2.837 \\
\mathrm{p}=0.045 \\
\mathrm{R}^{2}=0.117 \\
\text { Adj } \\
\mathrm{R}^{2}=0.076\end{array}$} & \multicolumn{2}{|c|}{$\begin{array}{l}\mathrm{F}=2.134 \\
\mathrm{p}=0.087 \\
\mathrm{R}^{2}=0.119 \\
\text { Adj } \\
\mathrm{R}^{2}=0.063\end{array}$} \\
\hline
\end{tabular}

Note: $* * *$ sig. at $0.00 ; * *$ sig. at $0.05 ; *$ sig. at 0.10 
Table 11: Mediating effect of learning orientation on relationship between MCS interactive use and organisational performance

\begin{tabular}{|c|c|c|c|c|c|c|c|c|c|c|c|c|}
\hline & \multicolumn{4}{|c|}{ Overall Performance } & \multicolumn{4}{|c|}{ Financial performance } & \multicolumn{4}{|c|}{ Non-financial performance } \\
\hline & \multicolumn{2}{|c|}{ Model 1} & \multicolumn{2}{|c|}{ Model 2} & \multicolumn{2}{|c|}{ Model 1} & \multicolumn{2}{|c|}{ Model 2} & \multicolumn{2}{|c|}{ Model 1} & \multicolumn{2}{|c|}{ Model 2} \\
\hline & $\begin{array}{c}\mathrm{t}- \\
\text { value }\end{array}$ & Sig & $\begin{array}{c}\mathrm{t}- \\
\text { value }\end{array}$ & Sig & $\begin{array}{c}\mathrm{t}- \\
\text { value }\end{array}$ & Sig & $\begin{array}{c}\mathrm{t}- \\
\text { value }\end{array}$ & Sig & $\begin{array}{c}\mathrm{t}- \\
\text { value }\end{array}$ & Sig & $\begin{array}{c}\mathrm{t}- \\
\text { value }\end{array}$ & Sig \\
\hline Constant & 4.85 & 0.00 & 2.63 & 0.01 & 3.00 & 0.00 & 1.08 & 0.28 & 5.36 & 0.00 & 3.56 & 0.00 \\
\hline Size & 2.75 & 0.01 & 3.23 & 0.00 & 2.79 & 0.01 & 3.30 & 0.00 & 1.67 & 0.10 & 1.89 & 0.06 \\
\hline Industry & 0.86 & 0.39 & 0.76 & 0.45 & 1.43 & 0.16 & 1.34 & 0.19 & -0.19 & 0.85 & -0.25 & 0.80 \\
\hline $\begin{array}{l}\text { MCS } \\
\text { interactive } \\
\text { use }\end{array}$ & 3.01 & $0.00 * * *$ & 2.27 & $0.03 * *$ & 3.02 & $0.00 * * *$ & 2.25 & $0.03 * *$ & & $0.07 *$ & 1.41 & 0.16 \\
\hline \multirow[t]{2}{*}{$\begin{array}{l}\text { Learning } \\
\text { orientation }\end{array}$} & & & 2.07 & $0.04 * *$ & & & 2.18 & $0.03 * *$ & & & 1.12 & 0.27 \\
\hline & \multicolumn{2}{|c|}{$\begin{array}{l}\mathrm{F}=6.840 \\
\mathrm{p}=0.000 \\
\mathrm{R}^{2}=0.243 \\
\text { Adj } \mathrm{R}^{2}=0.207\end{array}$} & \multicolumn{2}{|c|}{$\begin{array}{l}\mathrm{F}=6.454 \\
\mathrm{p}=0.000 ; \\
\mathrm{R}^{2}=0.291 \\
\text { Adj } \mathrm{R}^{2}=0.246\end{array}$} & \multicolumn{2}{|c|}{$\begin{array}{l}\mathrm{F}=6.952 \\
\mathrm{p}=0.000 \\
\mathrm{R}^{2}=0.246 \\
\mathrm{Adj} \\
\mathrm{R}^{2}=0.210\end{array}$} & \multicolumn{2}{|c|}{$\begin{array}{l}\mathrm{F}=6.706 \\
\mathrm{p}=0.000 \\
\mathrm{R}^{2}=0.299 \\
\text { Adj } \mathrm{R}^{2}=0.254\end{array}$} & \multicolumn{2}{|c|}{$\begin{array}{l}\mathrm{F}=2.84 ; \\
\mathrm{p}=0.045 \\
\mathrm{R}^{2}=0.117 \\
\text { Adj } \\
\mathrm{R}^{2}=0.076\end{array}$} & \multicolumn{2}{|c|}{$\begin{array}{l}\mathrm{F}=2.45 \\
\mathrm{p}=0.000 \\
\mathrm{R}^{2}=0.135 \\
\text { Adj } \mathrm{R}^{2}=0.08\end{array}$} \\
\hline
\end{tabular}

Note: ${ }^{* * *}$ sig. at $0.00 ; * *$ sig. at $0.05 ; *$ sig. at 0.10

Table 10 shows that technology capability only partially mediates the relationship between interactive MCS and financial performance. Learning orientation, as indicated in Table 11, also similarly mediates partially the relationship between MCS interactive usage and financial performance as well as that between MCS interactive use and the overall organisational performance.

As shown in Model 1 of Tables 9 to 11, an interactive MCS usage significantly impacts the financial dimension of organisational performance positively, while its impact on the non-financial dimension is only marginal. The findings suggest that the performance measurement systems of the sample organisations are placing greater emphasis on financial measures than on non-financial ones, and it is consistent with that reported by Ruzita and Panell (2008). Top managers in the sample companies, through the interactive use of MCS, tend to signal and direct their subordinates' attention more to the financial implications of the capability development necessitated by their new strategic initiatives. Results of the regression of the various capabilities on organisational performance, as shown in Table 8, indicate that only two capabilities - technology capability and learning orientation - affect financial performance. Panell (2011) reports that companies pursuing low-cost-differentiation combined strategy are associated with technology capabilities and managerial capabilities. Based on the findings of the current study, the sample companies may likely be pursuing similar low-cost-differentiation combined strategy. Organisations in emerging economies such as Malaysia are likely to lack the sophisticated technological and knowledge resources to effectively develop innovation capabilities (Panell, 2011) and the market responsiveness and strategic networking capabilities.

Empirical evidence of this study generally supports the proposition that organisational capabilities mediate the relationship between MCS interactive use and organisational performance. However, the mediating role of specific individual capability is mixed and is likely to be contextual dependent. In this study, technology capability and learning orientation are found to mediate the relationship between interactive use of MCS and organisational financial performance, while Henri (2006) finds that innovation and learning mediate the relationship between MCS interactive use and performance.

\section{DISCUSSION}


The first hypothesis of this study is to determine the level of association between the interactive use of MCS and organisational capabilities. The results suggest that direct relationship exists between an interactive MCS and organisational capabilities. These results are consistent with the arguments by Chenhall (2005), Bisbe et al. (2007), and Rehman, Mohamed \& Ayoup (2019) that interactive use of MCS leads to improve organisational capabilities. The direct relationship between using MCS interactively and market responsiveness is also consistent with the findings of Nobel et al. (2006). In the modern era, the ever changing environment pushes firms to act base on the changing needs of customers. The findings further support the idea of Colletti et al. (2005) and Beimborn et al. (2009) who also find a positive relationship between MCS interactive use and trust. They emphasise that in any organisation, exchange and transfer of information must take place with trust and commitment. The second subhypothesis also signifies the interactive use of MCS and learning. The results suggest that if firms adopt the interactive system, it will help them to ease the information processing system (Widener, 2007; Bedford, 2020).

Another finding of this study is the development of an innovation system through the use of MCS interactively, which is consistent with the studies of Henri (2006), Simons (1995), Davila et al. (2009), and Lill, Wald, \& Munck (2020). Interactive MCS helps the development of new ideas and creativity within an organisation.

The study confirms positive relationship between interactive use of MCS and process reliability and efficiency. It implies that managers may adopt the technology-based system which helps organisations to make effective decisions to improve their productivity and trustworthiness.

The second set of hypotheses is to investigate the relationship between organisational capabilities and organisational performance. The outcome of the analysis indicates a significant and positive relationship between overall capabilities and performance. The findings suggest that increasing organisational capabilities result in greater organisational performance. The findings are in line with the results of Henri (2006), Widener (2007), and Lill, Wald, \& Munck (2020). Current study results are also consistent with the findings of Ittner \& Larcker (1998) and Banker, Potter \& Srinivasan (2000), who note that non-financial measures are drivers of future organisational performance.

This study finds that each type of capabilities, individually, has a significant relationship with performance. The positive relationship between innovativeness and performance is consistent with that of Henri (2006). According to Sciarelli, Gheith, \& Tani (2020), innovation is one of the key elements that determine organisational performance. This study also uncovers a direct and positive relationship between learning and performance that is consistent with the findings of Chenhall (2005) and Henri (2006). Tippins \& Sohi (2003) and Jiménez-Jiménez \& Sanz-Valle (2011) also conclude that organisational learning is positively associated with a firm's performance. Hence, companies may learn how to recognise new changes in the market in order to adapt themselves to survive in the competitive environment and enhance their learning and performance.

The findings of the relationship between market responsiveness and performance are consistent with those of Nobel et al. (2006), who report that firms that have the ability to respond quickly to changes in environment have higher organisational performance.

However, when all five types of capabilities are analysed together, only process reliability and efficiency capability are significant with performance. It appears that among the five types of capabilities, process reliability and efficiency capability have the most significant impact on organisational performance. However, it does not mean that other types do not impact performance. What it means is that the sample companies' similar emphasis on performance and the different effects of market responsiveness, strategic networking, innovativeness and learning on organisational performance are also evident among these companies, but the effect of process reliability and efficiency on performance is more evident. Additional analyses show that process reliability and efficiency have significant relationship with financial performance. It means that the sample companies rely more on production processes; so, they need to invest more on computerised technologies to be able to react to the needs of their customers.

The third set of hypothesis is based on mediation of organisational capabilities between interactive use of MCS and organisational performance. RBV theory explains that control systems are not a source of competitive advantage, but they do help organisations to achieve those resources that they control. Therefore, control systems may not directly link to performance. Results of this study indicate an indirect relationship between interactive MCS and performance through overall capabilities. Previous studies (e.g., Bisbe \& Otley, 2004; Rehman, Mohamed, \& Ayoup, 2019) argue differently, and their studies have different results as compared to the current study. Current study data show the effects interactive uses of MCS have on performance, which is explained by the firms' capabilities. However, Henri (2006) has different findings in his study, where innovation and learning mediate the relationship between interactive use of MCS and performance.

Results of this study show that overall organisational capabilities fully mediate the relationship between using MCS interactively and performance. It signifies that there is no direct relationship between MCS and performance. 
However, apart from process reliability and efficiency capability, other types of capabilities have no relationship with performance. Therefore, they do not have the mediation effects. Regression results for process reliability and efficiency show that this capability partially mediates the relationship between interactive use of MCS and performance. Partial mediation suggests that there are other factors that also explain the relationship between interactive MCS and performance.

The results indicate that MCS can help organisation to improve organisational capabilities for competitive advantage. The findings are in line with the RBV theory. RBV theory explains how capabilities influence organisational performance. Therefore, this study is a valuable addition to the MCS literature.

\section{CONCLUSION AND IMPLICATIONS}

The purpose of this study is to examine the interactive use of MCS, organisational capabilities and organisational performance from a RBV perspective and in the context of Malaysia. This study provides empirical evidence that interactive use of MCS facilitates the development of organisational capabilities and that organisational capabilities play a mediating role in the relationship between using MCS interactively and organisational performance.

Further analyses in this study, however, indicate that only technology capability and learning orientation are significantly associated to the financial dimension of organisational performance. The findings of this study may have some theoretical and practical implications. The findings support the conceptual framework by Franco-Santos et al., (2012) that the PMS in MCS influences how managers assess and justify the organisational capabilities to be developed and that subsequently impact organisational performance. Top managers through their interactive use of the PMS signal to their subordinates the desired decision criteria for development of capabilities to enhance organisational performance. In addition, this study indicates that many companies in Malaysia still focus on financial measures rather than on non-financial ones in most of their decision making. Managers who are short-term focused or financially oriented in their decision making may jeopardise the long-term sustainability of their organisation's performance.

There are a few limitations in this study. The small sample size and the cross-sectional study may reduce the generalisability of the findings of this study. In addition, this study may also have the inherent methodological limitations associated with questionnaire investigation. Notwithstanding these limitations, this study enhances our understanding of how the interactive use of MCS influences development of organisational capabilities that in turn affects organisational performance in a developing country.

\section{REFERENCES}

Abernethy, M.A. and Brownell, P. 1999. The role of budgets in organisations facing strategic change, Accounting, Organisations and Society Vol.24 No. 3, pp. $189-204$.

Agbejule, A. 2011. Organisational culture and performance: the role of management accounting system. Journal of Applied Accounting Research Vol. 12 No. 1, pp. $74-89$.

Agyemang, G., and Broadbent, J., 2015.Management control systems and research management in universities. Accounting, Auditing \& Accountability Journal Vol. 28 Iss 7 pp. $1018-1046$

Alegre, J., and Pasamar, S., 2017. Firm innovativeness and work-life balance, Technology Analysis \& Strategic Management. Technology Analysis \& Strategic Management.

Barney, J.B. 1991. Firms resources and sustained competitive advantage. Journal of Management vol. 17 No.1, pp. $99-120$.

Baron, R.M. and Kenny, D.A. 1986. The moderator-mediator variable distinction in social psychological research: conceptual, strategic and statistical considerations. Journal of Personality and Social Psychology Vol. 6, pp. 1173 -1182 .

Banker, R. D., Potter, G., \& Srinivasan, D. 2000. An empirical investigation of an incentive plan that includes nonfinancial performance measures. The accounting review 75(1), 65-92.

Beimborn, D., Schlosser, F., \& Weitzel, T. 2009. Examining the relationship between trust and control in IT outsourcing relationships. Paper presented at the 17th European Conference on Information Systems (ECIS09), Verona, Italy. 
Bhatt, G.D. 2000. Exploring the relationship between information technology, infrastructure and business process re-engineering. Business Process Management Journal vol. 6 No. 2, pp. $139-163$.

Bisbe, J. and Otley, D. 2004. The effects of interactive use of management control systems on product innovation, Accounting, Organisations and Society Vol.29 No. 8, pp. $709-737$.

Bisbe, J., Batista-Foguet, J. M., \& Chenhall, R. 2007. Defining management accounting constructs: A methodological note on the risks of conceptual misspecification. Accounting, organizations and society 32(7-8), 789-820.

Brennan, M.S. and Hoek, J. 1992.The behavior of respondents, non-respondents, and refusers across mail surveys.Public Opinion Quarterly Vol.56, pp. 530 - 535.

Bronzo, M., de Oliveira, M.P.V. and McCormack, K. 2012. Planning, capabilities and performance: an integrated value approach. Management Decision Vol. 50 No. 6, pp. $1001-1021$.

Burke, W.W. 1989.Culture Instrument. Working paper, Columbia University.

Cadogan, J.W. 2012. International marketing, strategic orientations and business success: reflections on the path ahead. Int Mark Rev 29(4):340-348

Capon, N., Farley, J.U., Lehmann, D.R. and Hulbert, J.M. 1992. Profiles of product innovators among large U.S. manufacturers. Management Science Vol.38, pp. $157-169$.

Coller, G., Frigotto, M. L., \& Costa, E. 2018. Management control system and strategy: the transforming role of implementation. Journal of Applied Accounting Research.

Chae, H.C., Koh, C. E., Park, K.O. 2018. Information technology capability and firm performance: Role of industry. Journal of Information and Management. Information \& Management 55, 525-546.

Chapman, C.S. 1997.Reflections on a contingency view of accounting. Accounting, Organisations and Society Vol.22, pp. $189-205$.

Chenhall, R.H. 2003. Management control system design within its organisational context: findings from contingency-based research and directions for the future. Accounting, Organisations and Society Vol.28 No. 2-3, pp. $127-168$.

Chenhall, R. H. 2005. Integrative strategic performance measurement systems, strategic alignment of manufacturing, learning and strategic outcomes: an exploratory study. Accounting, organizations and society 30(5), 395-422.

Clark, K.B. and Fujimoto, T. 1991. Product Development Performance, Harvard Business School Press, Boston.

Coller, G., Frigotto, M. L., Costa, E. 2018. Management control system and strategy: the transforming role of implementation. Journal of Applied Accounting Research.

Collis, D.J. and Montgomery, C.A. 1995. Competing on resources. Harvard Business Review Vol. 73 No. 4, pp. 118 $-128$.

Collis, D.J. and Montgomery, C.A. 1998.Creating corporate advantage. Harvard Business Review Vol. 76 No. 3, pp. $70-83$.

Coletti, A. L., Sedatole, K. L., \& Towry, K. L. 2005. The effect of control systems on trust and cooperation in collaborative environments. The Accounting Review 80(2), 477-500.

Danneels, E. 2002.The dynamics of product innovation and firm competences. Strategic Management Journal Vol.23 No.12, pp. $1095-1121$.

Davila, T. 2000. An empirical study on the drivers of management control system design in new product development. Accounting, Organisations and Society Vol.25 No. 4-5, pp. $383-410$.

Eisenhardt, K.M. and Martin, J.A. 2000. Dynamic capabilities: What are they? Strategic Management Journal, Vol. 21, No. 10/11. pPp. $105-1121$.

Evans, J., Bridson, K., Byrom, J., \& Medway, D. 2005. The mediating role of competitive advantage in the relationship between organisational capabilities and retail performance. In ANZMAC 2005: Broadening the boundaries, conference proceedings (pp. 21-27). University of Western Australia, School of Business.

Franco, M. and Bourne, M. 2003. Factors that play a role in "managing through measures'. Management Decision Vol.41 No. 8, pp. $698-710$.

Franco-Santos, M., Lucianetti, L. and Bourne, M. 2012.Contemporary performance measurement systems: A review of their consequences and a framework for research. Management Accounting Research Vol. 23, pp. $79-119$.

Feng, H., Morgan, N.A. and Rego, L.L. 2017.Firm capabilities and growth: the moderating role of market conditions. Journal of the Academy of Marketing Science Vol. 45 No. 1, pp. 76- 92.

Grafton, J., Lilis, A.M. and Widener, S. K. 2010.The role of performance measurement and evaluation in building organisational capabilities and performance. Accounting, Organisations and Society Vol. 35, pp. 689-706. 
Golgeci, L., and Ponomarov., S. Y., 2015. How Does Firm Innovativeness Enable Supply Chain Resilience? The Moderating Role of Supply Uncertainty and Interdependence. Technology Analysis \& Strategic Management 27 (3): 267-282.

Govindarajan, V. 1986. Impact of participation in the budgetary process on managerial attitudes and performance: universalistic and contingency perspectives. Decision Sciences Vol. 17, pp. $496-516$.

Hamzah, H., Zakaria, S. and Yusof, W.F.W 2011. Determinants of balanced scorecard usage based on firm level and individual level perceptions in Malaysia, Proceedings of $2^{\text {nd }}$ International Conference on Business and Economic Research.

Henri, J.F. 2006. Management control systems and strategy. Accounting, Organisations and Society Vol. 31, pp. 529-558.

Helfat, C. E., Finkelstein, S., Mitchell, W., Peteraf, M., Singh, H., Teece, D., \& Winter, S. G. 2009. Dynamic capabilities: Understanding strategic change in organizations. John Wiley \& Sons.

Horngren, C; Dtar, S \& Rajan, M. 2012. Cost Accounting: A managerian emphasis. 6th edition, Pearson Prentige Hall.

Hoskisson, R.E., Hitt, M.A. \& Ireland, R.D. 2004. Cooperative Strategy. Thomson Learning: South Western.

Hult, G.T.M. 1998. Managing international strategic sourcing process as a market-driven organisational learning system. Decision Sciences Vol.29 No. 1, pp. $193-216$.

Hurley, R.F. and Hult, G.T.M. 1998. Innovation, market orientation, and organisational learning: an integration and empirical examination. Journal of Marketing Vol.62, pp. 42 - 54.

Ittner, C. D., \& Larcker, D. F. 1998. Are nonfinancial measures leading indicators of financial performance? An analysis of customer satisfaction. Journal of accounting research 36, 1-35.

Ittner, C., Larcker, D. and Randall, T. 2003. Performance implications of strategic performance measurement in financial services firms. Accounting, Organisations and Society Vol. 28, pp. 715-741.

Jiménez-Jiménez, D., \& Sanz-Valle, R. 2011. Innovation, organizational learning, and performance. Journal of business research 64(4), 408-417.

Kaplan, R.S. and Norton, D.P. 1992. The balanced scorecard - measures that drive performance. Harvard Business Review January - February, pp. 71 -79.

Krzakiewicz, K., Cyfert, S., 2019. Strategic orientations of the organization - entrepreneurial, market and organizational learning. Journal of Management. Vol. 23, No. 1.

Kwon, I.W. and Suh, T. 2005.Trust, commitment and relationships in supply chain management: a path analysis. Supply Chain Management: An International Journal Vol. 10 No. 1, pp. 26 - 33.

Langfield-Smith, K. 1997. Management control systems and strategy: a critical review. Accounting, Organisations and Society Vol. 22 No. 2, pp. $207-232$.

Lawson, B. and Somson, D. 2001. Developing innovation capability in organisation: a dynamic capabilities approach. International Journal of Innovation Management Vol. 5 No. 3, pp. 377 - 400.

Lee, C., Lee, K. and Pennings, J.M. 2001. Internal capabilities, external networks, and performance: a study of technology-based ventures. Strategic Management Journal Vol. 22 No. 6-7, pp. 615 - 640.

Lill, P., Wald, A., \& Munck, J. C. 2020. In the field of tension between creativity and efficiency: a systematic literature review of management control systems for innovation activities. European Journal of Innovation Management.

Grafton,J., Lilis, A.M. and Widener, S.K. 2010. The role of performance measurement and evaluation in building organisational capabilities and performance. Accounting, Organisations and Society Vol. 35 No. 7, pp. 689 - 706.

Franco-Santosa, M., Lucianettib, L. and Bourne, M. 2012. Contemporary performance measurement systems: A review of their consequences and a framework for research. Management Accounting Research Vol. 23, pp. 79119.

Martin, M. A. 2020. An evolutionary approach to management control systems research: A prescription for future research. Accounting, Organizations and Society, 86, 101186.

Morgan, R. M. and Hunt, S.D. 1994. The commitment-trust theory of relationship marketing. Journal of Marketing Vol. 58, pp. $20-38$.

Neely, A. D. and Bourne, M. 2000. Why measurement initiatives fail?” Measuring Business Excellence, Vol. 4 No. 4 , pp. $3-6$.

Newbert, S.L. 2007. Empirical research on resource-based view of the firm: an assessment and suggestions for future research. Strategic Management Journal Vol. 28, pp. 121 - 146.

Nunnally, J.C. and Bernstein, I.H. 1994. Psychometric Theory ( ${ }^{\text {rd }}$ Ed.), McGraw-Hill, New York.

Nobel, S.M., Griffith, D.A. and Chen, Q. 2006. The performance implications of entrepreneurial proactivity: a dynamic capabilities approach. Journal of Retailing pp. $51-62$. 
Obeng, B.A., 2018. Strategic networking and small firm growth in an emerging economy. Journal of Small Business and Enterprise Development, 1462-6004.

Ojha, D., Struckell, E., Acharya, C., \& Patel, P. C. 2020. Managing environmental turbulence through innovation speed and operational flexibility in B2B service organizations. Journal of Business \& Industrial Marketing.

Oktavio, A., Kaihatu, T.S., Kartika, E. W., 2019. Learning orientation, entrepreneurial orientation, innovation and their impacts on new hotel performance: evidence from Surabaya. Journal of Applied Management (JAM) Volume 17 Number 1.

O'Reagan, N. and Ghobadian, A. 2004. The importance of capabilities for strategic direction and performance, Management Decision Vol. 42 No. 2, pp. $292-312$

Otley, D. T. 1980. The contingency theory of management accounting: achievement and prognosis. In Readings in accounting for management control (pp. 83-106). Springer, Boston, MA.

Otley, D. 2003. Management control and performance measurement: whence and whither. The British Accounting Review Vol. 35 No. 4, pp. 309 - 326.

Parnell, 2011. Strategic capabilities, competitive strategy and performance among retailers in Argentina, Peru and the United States. Management Decision Vol. 49 No. 1, pp. $130-155$.

Pavlov, A. and Bourne, M. 2011. Explaining the effects of performance measurement on performance: an organisational routines perspective. International Journal of Operations \& Production Management Vol. 31 No. 1, pp. 101-122

Pehrsson, A., 2019. When are innovativeness and responsiveness effective in a foreign market?, Journal of International Entrepreneurship 17:19-40

Rehman, S. U., Mohamed, R., \& Ayoup, H. 2019. The mediating role of organizational capabilities between organizational performance and its determinants. Journal of Global Entrepreneurship Research 9(1), 1-23.

Ruzita, J. and Parnell, J.A. 2008). Competitive strategy and performance measurement in the Malaysian context: an exploratory study. Management Decision Vol. 46, No. 1, pp. $5-31$

Sambasivan, M., Siew-Phaik,L., Mohamed, Z. A. and Leong, Y.C. 2011. Impact of interdependence between supply chain partners on strategic alliance outcomes: role of relational capital as a mediating construct. Management Decision Vol. 49, No. 4, pp. 548 - 569.

Sciarelli, M., Gheith, M. H., \& Tani, M. 2020. The relationship between soft and hard quality management practices, innovation and organizational performance in higher education. The TQM Journal.

Simons, R. 1991. Strategic orientation and top management attention to control systems. Strategic Management Journal Vol. 12 No. 1, pp. $49-62$.

Simons, R. 1994. How new top managers use control systems as levers of strategic renewal. Strategic Management Journal Vol. 15 No. 3, pp. $169-189$.

Simons, R. 1995. Levers of Controls. Harvard Business School Press, Boston.

Snell, S.A. and Dean, J.W. 1992. Integrated manufacturing and human resources management: a human capital perspective. Academy of Management Journal Vol. 35 No. 3, pp. 467 - 486.

Sobanke, V., Ilori, M., Adegbite, S., 2012. Technological Capability in Metal Fabricating Firms in Southwestern Nigeria", American Journal of Industrial and Business Management 2(4), 2012, 176-183

Sobanke, V., Adegbite, S., Ilori, M., Egbetokun, A., 2014. Determinants of Technological Capability of Firms in a Developing Country.

Solesvik, M. 2018. The Rise and Fall of the Resource-Based View: Paradigm Shift in Strategic Management. Journal of the Ural State University of Economics, vol. 19, no. 4, pp. 5-18.

Stank, T.P., Davis, B.R. and Fugate, B.S. 2005. A strategic framework for supply chain oriented logistics. Journal of Business Logistics Vol. 26 No. 2, pp. 27 - 45.

Teece, D.J., Pisano, G. and Shuen, A. 1997. Dynamic capabilities and strategic management. Strategic Management Journal Vol.18 No. 7, pp. $509-533$.

Thrikawala, S.S., .2011. Impact of Strategic Networks for the Success of SMEs in Sri Lanka. World Journal of Social Sciences Vol. 1. No. 2. Pp. $108-119$.

Tippins, M.J. and Sohi, R.S. 2003. IT competency and firm performance: is organisational learning a missing link?. Strategic Management Journal Vol. 24, pp. 745 - 761.

Toldbod, T., \& van der Kolk, B. 2020. Cascading Control Changes, Incoherence, and Dialogue: Insights from a Longitudinal Case Study. European Accounting Review, 1-31.

Webster, C. 2006. An empirical analysis of the relationships between the interactive use of performance measurement systems, creativity and performance: the intervening role of psychological empowerment. Paper presented at the $29^{\text {th }}$ Annual Congress of the European, Monash University.

Wernerfelt, B. 1984. A resource-based view of the firm. Strategic Management Journal Vol. 5 No.2, pp. $171-180$. 
Widener, S.K. 2007. An empirical analysis of the levers of control framework. Accounting, Organisations and Society Vol. 32, pp. 757-788.

Tze San Ong*

School of Business and Economics

Universiti Putra Malaysia

43400 Serdang, Selangor

MALAYSIA

E-mail: tzesan@upm.edu.my

Zohreh Haghshenas

School of Business and Economics

Universiti Putra Malaysia

43400 Serdang, Selangor

MALAYSIA

E-mail: zohrehhaghshenas@yahoo.com

Boon Heng Teh

Faculty of Management

Multimedia University

63100 Cyberjaya, Selangor

MALAYSIA.

E-mail: bhteh@mmu.edu.my

Babatunji Samuel Adedeji

School of Business and Economics

Universiti Putra Malaysia

43400 Serdang, Selangor

MALAYSIA

E-mail: samtunji2014@gmail.com

Hussain Bakhsh Magsi

Water and Marine Sciences (LUAWMS)

University of Agriculture

Uthal, Las Bela, Balochistan 90150

PAKISTAN.

E-mail: husane.magsi@gmail.com

*Corresponding author 